\title{
Regional spread of HIV-1 M subtype B in middle-aged patients by random env-C2V4 region sequencing
}

\author{
Martin Stürmer · Katrin Zimmermann • Carlos Fritzsche $\cdot$ Emil Reisinger • \\ Gottfried Doelken · Annemarie Berger · Hans W. Doerr · Josef Eberle • \\ Lutz G. Gürtler
}

Received: 12 October 2009/Published online: 9 March 2010

(c) The Author(s) 2010. This article is published with open access at Springerlink.com

\begin{abstract}
A transmission cluster of HIV-1 M:B was identified in 11 patients with a median age of 52 (range 2665) in North-East Germany by $\mathrm{C} 2 \mathrm{~V} 4$ region sequencing of the env gene of HIV-1, who-except of one-were not aware of any risky behaviour. The 10 male and 1 female patients deteriorated immunologically, according to their information made available, within 4 years after a putative HIV acquisition. Nucleic acid sequence analysis showed a R5 virus in all patients and in 7 of 11 a crown motif of the V3 loop, GPGSALFTT, which is found rarely. Analysis of formation of this cluster showed that there is still a huge discrepancy between awareness and behaviour regarding HIV transmission in middle-aged patients, and that a local outbreak can be detected by nucleic acid analysis of the hypervariable env region.
\end{abstract}

M. Stürmer · A. Berger · H. W. Doerr · L. G. Gürtler ( $\square)$ Institute for Medical Virology, University Hospital Frankfurt, Paul Ehrlich Str 40, 69596 Frankfurt, Germany

e-mail: lutzg.guertler@vodafone.de

K. Zimmermann · L. G. Gürtler

Friedrich Loeffler Institute for Medical Microbiology,

University Hospital Greifswald, Martin Luther Str 6,

17489 Greifswald, Germany

C. Fritzsche $\cdot$ E. Reisinger

Clinics for Internal Medicine and Tropical Medicine,

University Rostock, Rostock, Germany

G. Doelken

Clinics for Internal Medicine C, University Hospital Greifswald, Greifswald, Germany

J. Eberle

Max von Pettenkofer Institute, University München,

Pettenkofer Str 9A, 80336 Munich, Germany
Keywords HIV transmission · Epidemiology · Cluster · Risky behaviour - Local outbreak . Middle-aged people

\section{Introduction}

The route of sexual spread of human immunodeficiency virus (HIV) is known since 1981 [1]. Awareness of spread of this infectious agent in different parts and different people of Germany is variable, with a trend that especially young homosexual men (MSM) are predominantly affected [2].

The aim of this study was to find the route of transmission of HIV infection in a few patients who presented with AIDS or AIDS-like symptoms in a group of middleaged people non-exposed to obvious epidemiological or individual risk factors.

\section{Patients}

All patients, 10 males and 1 female, were born and/or living in a geographically restricted area around Greifswald. Patients' data are summarized in Table 1. Patients had been identified and analysed as HIV infected either according to their clinical AIDS-defining symptoms or after getting information that a sexual partner was found to be HIV infected. One of the patients was identified when he desired to donate blood.

Most patients could not explain how, when and where they acquired their HIV infection. Only one of the male patients named his HIV-infected source partner; he stated to be HIV antibody negative before his homosexual relationship started with the index patient. This index patient 
Table 1 Demographic data, laboratory test results, and clinical parameters obtained from the patients included in this study

\begin{tabular}{|c|c|c|c|c|c|c|c|c|}
\hline $\begin{array}{l}\text { Patient } \\
\text { number }\end{array}$ & Sex & $\begin{array}{l}\text { Age at } \\
\text { diagnosis }\end{array}$ & $\begin{array}{l}\text { Viral load }(\mathrm{cop} / \mathrm{ml}) \\
\text { at the first hospital visit }\end{array}$ & $\begin{array}{l}\text { CD4 cells/ } \mu \text { l at } \\
\text { diagnosis }\end{array}$ & $\begin{array}{l}\text { Coreceptor } \\
\text { tropism R5/X4 }\end{array}$ & $\begin{array}{l}\text { V3 loop crown } \\
\text { motif }\end{array}$ & $\begin{array}{l}\text { Disease } \\
\text { stage }\end{array}$ & $\begin{array}{l}\text { Main } \\
\text { symptoms }\end{array}$ \\
\hline HGW1 & M & 61 & 48,000 & 550 & R5 & GPGRALYST & $\mathrm{C} 1$ & Atrophic dermatitis \\
\hline HGW2 & M & 48 & 310,000 & 270 & R5 & GPGSALFTT & $\mathrm{C} 3$ & $\begin{array}{l}\text { Weight loss } \\
\text { Neurologic }\end{array}$ \\
\hline HGW3 & M & 46 & 125,000 & 150 & R5 & GPGRALFTT & $\mathrm{C} 3$ & Neurologic \\
\hline HGW4 & M & 57 & 72,000 & 120 & R5 & $\begin{array}{l}\text { RPGSALFTT }^{\mathrm{a}} \\
\text { GPGSALFTT }\end{array}$ & $\mathrm{C} 3$ & $\begin{array}{l}\text { Marasmus } \\
\text { Zoster }\end{array}$ \\
\hline HGW5 & $\mathrm{F}$ & 55 & 41,000 & 250 & R5 & GPGSALFTT & A2 & None \\
\hline HGW6 & M & 56 & 87,000 & 330 & R5 & GPGSALFTT & $\mathrm{C} 3$ & $\begin{array}{l}\text { Weight loss } \\
\text { Pemphigus }\end{array}$ \\
\hline HGW7 & M & 26 & 330,000 & 170 & R5 & GPGRALYTT & C3 & Weight loss \\
\hline HGW8 & M & 39 & 29,000 & 600 & R5 & GPGRALLTT & $\mathrm{C} 2$ & Candidiasis \\
\hline HGW9 & M & 65 & 11,000 & 650 & R5 & GPGSALFTT & A1 & None \\
\hline HGW10 & M & 64 & 32,000 & 540 & R5 & GPGSALFTT & $\mathrm{C} 2$ & None \\
\hline HGW11 & M & 52 & 280,000 & 45 & R5 & GPGSALFTT & C3 & $\begin{array}{l}\text { Weight loss } \\
\text { Candidiasis }\end{array}$ \\
\hline
\end{tabular}

${ }^{a}$ Both sequences were found in this patient, circulating in approximately equal amounts

was neither available for interview nor his blood for nucleic acid sequence analysis. Additionally, a person who might be the real source of spread of this HIV infection could not be traced, despite several efforts made.

\section{Materials and methods}

For nucleic acid sequence analysis, EDTA blood was drawn by venepuncture. HIV antibody was tested from the EDTA-plasma with a commercially available kit (Enzygnost, Dade-Behring, Marburg, Germany). Presence of antibody was confirmed by immunoblot (HIV-Innolia, Innogenetics, Ghent, Belgium). Viral load was determined by the Amplicor Monitor test (Roche, Alameda, CA, USA; no longer available). CD4 cells were measured by FACS analysis (Becton-Dickinson, Heidelberg, Germany).

RNA was extracted from EDTA-plasma according to the recommendation of the manufacturer (Qiagen, Hilden, Germany). RNA was transcribed to DNA by reverse transcription using a one step RT-PCR (Superscript, Invitrogen, Carlsbad, CA) at $50^{\circ} \mathrm{C}$ for $30 \mathrm{~min}$, followed by a nested PCR using Taq polymerase (Platinum Taq polymerase, Invitrogen, Carlsbad, CA). PCR-cycling conditions were denaturation at $92^{\circ} \mathrm{C}$ for $30 \mathrm{~s}$, annealing at $50^{\circ} \mathrm{C}$ for $90 \mathrm{~s}$, and elongation at $72^{\circ} \mathrm{C}$ for $90 \mathrm{~s}$, cycling 30 times. Final elongation was done at $72^{\circ} \mathrm{C}$ for $7 \mathrm{~min}$.

Primers used were (in $5^{\prime}$ to $3^{\prime}$ direction)

5env 6901: CCT CAg CCA TTA CAC Agg CCT gTC CAA Ag (HXB2 6818-6846) and 3env 7681: ATA TAA
TTC ACT TCT CCA ATT gTC (HXB2 7792-7616) for the first amplification step; and 5env 7001: gCA CAg TAC AAT gTA CAC ATg gAA (HXB2 6949-6974) and 3env7401: TTA CAg TAg AAA AAT TCT CCT C (HXB2 7380-7361) for the second amplification step.

Amplificates of the second/nested PCR were analysed by $2.5 \%$ agarose gel electrophoresis in the presence of ethidium bromide, and the specific band was after purification subjected to the dideoxynucleotide sequencing cycles [3] using the AbiPrism labelling kit and the 301 sequence analyser (Applied Biosystems, Weiterstadt, Germany). Sequences were analysed and aligned with the Sequence Navigator or BioEdit (http://www. mbio.ncsu.edu/BioEdit) program. Construction of the phylogenetic tree was performed using 372 nucleotides of the C2V4 region including the V3 loop by the Treecon and Mega 4 program [4, 5]. Pathogenicity index and X4/R5-coreceptor use was calculated according to the formula of Briggs et al. [6] weighing the charge of acidic and basic amino acid residues in the V3 loop.

Mutation rate was calculated using an average rate of $0.5 \%$ per year in the V3 loop published 1990 by Balfe et al. [7] for recently infected haemophiliacs, which is close to the data given by Ji and Loeb [8] of 2 in $10^{4}$ errors per base per replication cycle in the $V 1$ gene and of Salazar-Gonzales et al. [9] of $1.7 \times 10^{-5}$ substitution per site per day in the whole env gene in asymptomatic individuals, which is $0.6 \%$ per year. The average transition/transversion rate within the env/V3 was given with 1.42 [10], which is higher than in other parts of the env gene. 


\section{Results}

Patients

In comparison to other epidemiological studies that reported a clustering of HIV transmission, the high age of the majority of the patients, in average 52, range 26-65, is remarkable; additionally, it is striking that only one female was involved, who was most probably infected by her husband. Nine of the 11 patients showed a clinical presentation compatible with advanced signs of immunodeficiency.

Analysis of the nucleic acid sequence of the C2V4 region

The crown motif of the viruses could be ranked in two groups, GPGSALFTT, which was found in seven patients - in patient HGW4 an nearly equal mixture of the $\mathrm{N}$ terminal $\mathrm{G}$ and $\mathrm{R}$ was found-and GPGRALYST/ GPGRALYTT in the remaining four patients (Table 1). The codon AGT for the amino acid S (serine) was conserved in all sequences while a codon AGG (twice) and AGA (once) was used for $\mathrm{R}$ (arginine) in the GPGS or GPGR crown motif, indicating that an exchange of $G$ or $A$ by $\mathrm{T}$ in the third position was the drive for selection of serine. The codon of the aspartic acid (D) in amino acid position 321, within the C-terminal part of the V3 loop, was deleted in all sequenced strains of these patients (see below for three sequences and in Table 2), which is a rare event. However, it was found initially in the LAI/BRU virus (clone HXB2), as shown below (the one letter code of amino acids was used).

$\begin{array}{ll}\text { amino acid position/ } & \\ \text { strain } & 296 \\ \text { HXB2: } & \text { CTRPNNNTRKRIRIGPGRAFVTIG-KIGNMRQAHC } \\ \text { WEAU: } & \text { CTRPNNNTRKKITLGPGRVLYTTGDI IGDIRRAHC } \\ \text { HGW4 } & \text { CTRPNNNTRRGVHVRPGSALFTTH-IIGDIRQAHC } \\ \text { HGW5 } & \text { CTRPNNNTRRGVHVGPGSALFTTH-IIGDIRQAHC } \\ \text { HGW7 } & \text { CTRPNNNTRKGVHVGPGRALYTTH-IIGDIRQAHC }\end{array}$

Mutation rate and duration of HIV infection

Analysis of the nucleic acid sequences of the couple HGW4 and HGW5 revealed 80 mutations per 340 nucleotides in the $\mathrm{C} 2 \mathrm{~V} 4$ region. Considering a mutation rate in 2 individuals and an increase of mutations in the HGW4 patient with severe symptoms of AIDS of $1 \%$ per year [11], the time point of infection could have been 12 years ahead-around 1994. In contrast, the information given by the male patient on his putative infection time was 2002 . Another, homosexually active, patient of this cluster focused his time point of infection around 7 years ago, which is more close to the 12 years time point of divergence of the cluster of these patients.

\section{Phylogenetic tree}

Compared to the more than $100 \mathrm{HIV}-1$ subtype B strains analysed in our laboratories, all $\mathrm{C} 2 \mathrm{~V} 4$ sequences of the 11 patients clustered together and were thus epidemiologically linked (Fig. 1). Boot strap analysis revealed a value 57-86 of 100 for the branching of this cluster from all other subtype B sequences, running 1,000 comparisons. There was no difference between the tree constructed by the Treecon program or the Mega4 program, in both trees the cluster of the 11 sequences segregated separately from all other HIV-1 M B-subtypes. Within the 177 nucleic acid sequences of the $\mathrm{C} 2 \mathrm{~V} 4$ region analysed, and within all sequences available at the Los Alamos Data Base (update 2007), there was no other nucleic acid sequence identical to that of the majority of this cluster.

\section{Discussion}

This study describes a further cluster of HIV transmission to 11 patients in a locally restricted area identified by nucleic acid sequencing of part of the env gene region. By the same method, an intrafamiliar cluster of HIV-1 transmission involving three persons had been identified in France in 1998 [12], as well as heterosexual transmission of HIV-1 in Senegal [13] and in Belgium by a man originating from Rwanda who infected from 1992 to 1996 six recipients [14]. By nucleic acid sequence analysis of the pol gene, not the env gene, the transmission of multiple drug-resistant HIV in a cluster was determined [15]. Earlier reports describe the transmission of HIV-1 to 11 middleaged women by one man in Belgium 1989 [16], from one man to 13 women in 2002 in New York [17]. Genotypic signature characteristics with a lower charge of the V3 loop in the recipients had been described in a study in Uganda [18], this charge difference was not found in the cluster described here. Regional HIV outbreaks have been reported more recently in Quebec [19] especially during the acute/early period of HIV infection identifying at least 7 (range 2-17) transmission clusters involving 293 people with a medium age between 34 and $39 \pm 10$. Another study involved approximately 65 persons of whom at least three were infected heterosexually during a short period in Los Angeles in 2004 in the adult film industry where the index patient had an age of 40 [20]. 
Table 2 C2V4 amino acid sequences of the patients involved in the cluster, aligned to the HXB2 sequence

HGW1: QLLLNGSLAEEEVVIRSENFTDNAKTIIVQLTESVXINCTRP-NNNT-RKGVHV--GPGRALYS--TH-II--GDIRQAHCNISKANWNDTLKKIASKLRE--HFENKPIVLIQSS-GGDPKIV

HGW2: QLLLNGSLAEEEVVIRSENFTDNAKTIIVQLNESVVINCTSP-NNNT-RRGIHT--GPGSALFT--TH-II--GDIRQAYCNISRAKWNATLQKVATKLGE--QYSSTKIIFNSSS-GGDVEIV

HGW3: QLLLNGSLAEEEVVISSENFTDNAKTI IVQLNESVEINCARP-NNNT-RNSVHV--GPGRALFT--TH-II--GNIRQAHCNISRTNWTAALKNVATKLRE--QFNSTIIVFNSSS-GGDLLVV

HGW4: QLLLNGSLAEEEVMIRSENFTDNVKTIIVQLNESVQINCTRP-NNNT-RRGVHV--GPGSALFT--TH-II--GDIRQAHCNINRTKWNDALKKIATKLIE--QFNSXXIIFNSSS-GGDLEIE

HGW5: QLLLNGSLAEKEVMIRSENFTDNVKTIIVQLNESVEINCTRP-NNNT-RRGVHV--GPGSALFT--TH-II--GDIRQAHCNISRAKWNDTLKRIATKLRE--QFKNSTIFFNSSS-GGDIEIV

HGW6: QLLLNGSLAEEEVMIRSKNFTNNVDTIIVQLNESVEINCTRP-NNNT-RQSVHV--GPGSALFT--TN-II--GDIRQAHCNISRAKWNATLQKIATKLGE--RYNRTIXXFTSSS-GGDIEIT

HGW7: QLLLNGSLAEEEVVIRSENFTDNAKTI IVQLNETVKINCTRP-NNNT-RKGVHV--GPGRALYT--TH-II--GDIRQAHCNISRAKWNDTLKKVVTKLRE--QFNTTTIVFNSSS-GGDLEVV

HGW8: QLLLNGSLAEEEVVIRSENFTDNVKTIIVQLNESVTINCTRP-NNNT-RKGVHV--GPGRALLT--TH-II--GDIRQAYCNISRAEWSAALKKXVTKLRE--QFGNKTIVFNSSS-GGDLLIV

HGW9: QLLLNGSLAEGEVMIRSKNFTNNADTIIVQLNESVAINCTRP-NNNT-RKGVHV--GPGSALFT--TH-II--GDIRQAHCNISRTQWNTALQKIVTKLRE--RYNGXXITFNSSS-GGDLEIT

HGW10: QLLLNGSLAEGEVMIRSKNFTNNADTI IVQLNESVTINCTRP-NNNT-RKGVHV--GPGSALFT--TH-IM--GDIRQAHCNISRTQWKATLQKIVTKLRE--QYNGXXIIFNSSSS-GGDLVIT

HGW11: QLLLNGSLAEEEVVIRSEXFTDNVKTIIVQLNESVEINCTRP-NNNT-RRSVHV--GPGSALFT--TN-II--GDIRQAHCNISRAKWNATLQKVVAKLKE--QFPNKTIVFNTSS-GGDPEIV

The one letter code of amino acid sequences was used. In the middle, the GPGR motif of the crown of the V3 loop may be seen. The sequences start at the amino acid position 258 of HXB2 according to the sequence counting of Los Alamos data base (21)

Fig. 1 Phylogenetic tree of the nucleic acid sequences of 177 HIV's, including some reference sequences for comparative analysis of the HIV-1 group B sequences of the patients of the described cluster, drawn with the Mega 4 program. As may be seen in the lower part of the tree, marked with the red square, the cluster is formed by the 11 sequences (HGW1-11) and separated from all other sequences analysed in Greifswald (FLI), München (MVP) and Frankfurt (FFM). Roughly the position of subtype $\mathrm{B}$ strains (bow on the right), and of subtypes $\mathrm{A}, \mathrm{A} / \mathrm{E}$ and $\mathrm{F}$ (dashed lines) are given; the position of the 3 group $\mathrm{O}$ strains is indicated with a double line on the left upper end of the tree

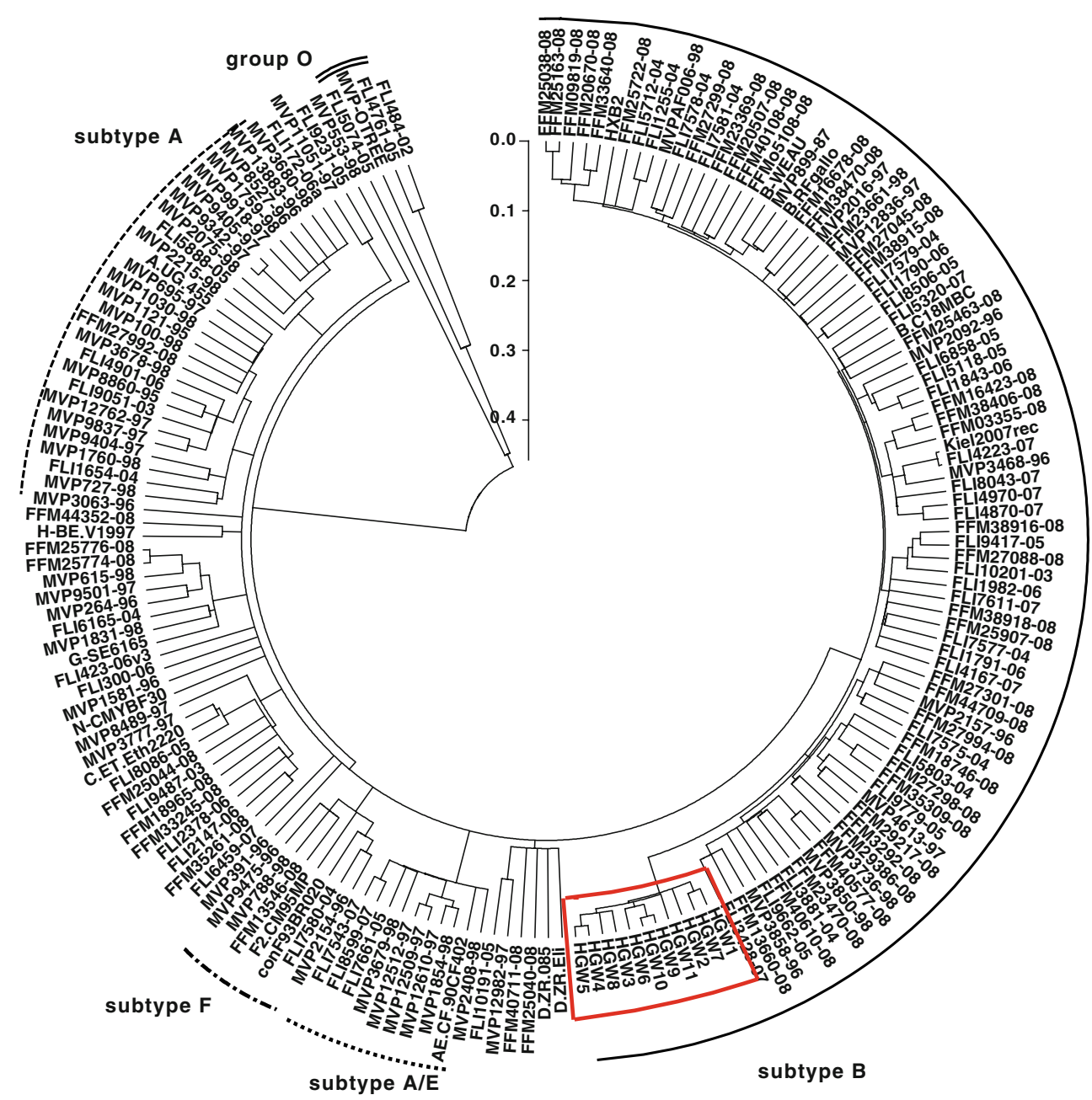

get valuable information. For the cluster analysis the choice of the HIV gene region is more important than the program used [21]. Further statistical methods, as maximum-likelihood or Bayesian approach, cannot support 
relationship of various HIV when there is a strong virologic link [22]—as described here.

The crown motif of the V3 loop with the amino acid sequence GPGSALFTT, which was found in 7 of the 11 patients, has not been deposed in the Los Alamos Data Bank (http://www.hiv.lanl.gov/) [23]. Beneath 1,766 sequences available there were 4 similar subtype B sequences with the crown motif GPGSALxxx or xxGSALFxx one from Spain (B.ES.xLPM.MHO2.EF531331), one from Ecuador (B.EC.89.EC102.AY173960), and two from United States, indicating how rare this sequence motif is.

The variant amino acids of those cited strains are as follows:

HGW 4

B.ES.XLPM.MHO2.EF531331

B.EC.89.EC102.AY173960

B.US.LC04A18_FLQ1018.M90933

B.US.LC04A2 FLQ102.M90931

Analysis of the therapy naïve patients of this cluster yielded the following peculiarities: a median age of approximately 52 , which is high compared to other studies $[18,20]$. According to the information given by the patients, unawareness of any risky behaviour in the past or inability to realize where and when risky behaviour had happened, as has been reported in previous studies as well $[16,24]$. All patients were carrying a R5 virus, despite the manifestation of full blown AIDS in 5 patients (see Table 1), and all viruses of this cluster had no mutations in the pol-gene linked to drug resistance of the protease and reverse transcriptase (data not shown).

Regarding this cluster, it is striking that only one female was involved, who was most probably infected by her husband. Additionally, 8 of the 11 patients were married. Despite the various efforts made the source-one or several index patients $[19,25,26]$ - and the route of HIV-1 transmission-homosexual, bisexual, heterosexual-in this cluster is still unclear. To get access to the source of infection, a further described way for cluster analysis is by partner notification, without nucleic acid sequencing [25, 27, 28], which was not possible for these 11 patients investigated.

The HIV infection of these patients opens a considerable gap of knowledge concerning HIV transmission in a nonpromiscuitive setting, since only one of the patients was willing or able to give information on his route of infection. Most of the patients involved were identified by deterioration of the immune system between 2005 and 2008. Low awareness of the risk of HIV transmission is a fundamental cofactor in the spread of HIV within communities. There had been several, annually repeated efforts to rise the level of awareness focused on the social status, on ethnic minorities, on sexual preference, on education, and on prevention modes [16, 23, 24, 28, 29]. This low awareness is not country dependent, mostly independent of funding, but highly dependent on human behaviour [26, 30]. The cluster described in this paper shows that besides young people and predominantly young MSM in the western world also elderly people are at risk of HIV acquisition and unaware of their risky behaviour even after 25 years of HIV counselling and information [31] and that information campaigns should address all age groups.

Acknowledgments We thank Claudia Cordt and Hanka Dürrfeld for excellent technical assistance.

Open Access This article is distributed under the terms of the Creative Commons Attribution Noncommercial License which permits any noncommercial use, distribution, and reproduction in any medium, provided the original author(s) and source are credited.

\section{References}

1. Gottlieb MD, Schroff R, Schanker HM, Weissman JD, Fan PT, Wolf RA, Saxon A (1981) Pneumocystis carinii pneumonia and mucosal candidiasis in previously healthy homosexual men. $\mathrm{N}$ Engl J Med 305:1425-1431

2. Hamouda O, Marcus U, Voss I, Kollan C (2007) Epidemiology of HIV infection in Germany. Bundesgesundbl Gesundforsch Gesundschutz 50:399-411

3. Sanger F, Nicklen S, Coulson AR (1977) DNA sequencing with chain-terminating inhibitors. Proc Natl Acad Sci USA 74:54635467

4. Van de Peer Y, De Wachter R (1997) Construction of evolutionary distance trees with Treecon for Windows: accounting for variation in nucleotide substitution rate among sites. Comput Appl Biosci 13:227-230

5. Tamura K, Dudley J, Nei M, Kumar S (2007) MEGA4: molecular evolutionary genetics analysis (MEGA) software version 4.0. Mol Biol Evol 24:1596-1599

6. Briggs DR, Tuttle DL, Sleasman JW, Goodenow MM (2000) Envelope V3 amino acid sequence predicts HIV-1 phenotype (coreceptor usage and tropism for macrophages). AIDS 14:29372939

7. Balfe P, Simmonds P, Ludlam CA, Bishop JO, Brown AJ (1990) Concurrent evolution of human immunodeficiency virus type 1 in patients, infected from the same source: rate of sequence change and low frequency of inactivating mutations. J Virol 64:62216233

8. Ji J, Loeb LA (1994) Fidelity of HIV-1 reverse transcriptase copying a hypervariable region of the HIV-1 env gene. Virology 199:323-330

9. Salazar-Gonzales JF, Bailes E, Pham KT, Salazar MG, Guffey MB, Keele BF, Derdeyn CA, Farmer P, Hunter E, Allen S, Manigart O, Mulenga J, Anderson JA, Swanstrom R, Haynes BF, Athreya GS, Korber BTM, Sharp PM, Shaw GM, Hahn BH (2008) Deciphering human immunodeficiency virus type 1 
transmission and early envelope diversification by single-genome amplification and sequencing. J Virol 82:3952-3970

10. Leitner T, Kumar S, Albert J (1997) Tempo and mode of nucleotide substitutions in gag and env gene fragments in human immunodeficiency virus type 1 populations with a known transmission history. J Virol 71:4761-4770

11. Diaz RS, Zhang L, Busch MP, Mosely JP, Mayer A (1997) Divergence of HIV-1 quasispecies in an epidemiologic cluster. AIDS 11:415-422

12. Beléc L, Si MA, Muller-Trutwin MC, Gilquin J, Gutmann L, Safar M, Barré-Sinoussi F, Kazatchkine MD (1998) Genetically related human immunodeficiency virus type 1 in three adults of a family with no identified risk factor for intrafamilial transmission. J Virol 72:5831-5839

13. Kane CT, Montavon C, Toure MA, Faye MA, Ndlaye AG, Diallo AG, Ndoye I, Liegeois F, Delaporte E, Mboup S, Peeters M (2001) Full-length genome sequencing of HIV-1 type 1 group O viruses isolated from a heterosexual transmission cluster in Senegal. AIDS Res Human Retroviruses 17:1211-1216

14. Lemey P, van Dooren S, van Laethem K, Schrooten Y, Derdelinckx I, Goubau P, Brun-Vézinet F, Vaira D, Vandamme AM (2005) Molecular testing of multiple HIV transmissions in a criminal case. AIDS 19:1649-1658

15. Buskin SE, Ellis GM, Pepper GG, Frenkel LM, Pergam SA, Gottlieb GS, Horwitch C, Olliffe JF, Johnson K, Shallit P, Heinen C, Schwartz M, Wood RW (2008) Transmission cluster of multiclass highly drug-resistant HIV-1 among 9 men who have sex with men in Seattle/King County, WA, 2005-2007. J Acquir Immune Defic Syndr 49:205-211

16. Clumeck N, Taelman H, Hermans P, Piot P, Schoumacher M, De Wit S (1989) A cluster of HIV infection among heterosexual people without apparent risk factors. N Engl J Med 321:1460 1462

17. Robbins KE, Weidle PJ, Brown TM, Saekhou AM, Coles B, Holmberg SD, Folks TM, Kalish ML (2002) Molecular analysis in support of an investigation of a cluster of HIV-1 infected women. AIDS Res Human Retroviruses 18:1157-1161

18. Sagar M, Laeyendecker O, Lee S, Gamiel J, Wawer MJ, Gray RH, Serwadda D, Sewankambo NK, Shepherd JC, Toma J, Huang W, Quinn TC (2008) Selection of HIV variants with signature genotypic characteristics during heterosexual transmission. J Infect Dis 199:580-589

19. Brenner BG, Roger M, Routy JP, Moisi D, Ntemgwa M, Matte C, Baril JG, Thomas R, Rouleau D, Bruneau J, Leblanc R, Legault M, Tremblay C, Charest H, Wainberg M (2007) High rates of forward transmission events after acute/early HIV-1 infection. J Infect Dis 195:951-958
20. Taylor M, Rotblatt H, Brooks JT, Montoya J, Aynalem G, Smith L, Kenney K, Laubacher L, Bustamante T, Kim-Farley R, Fielding J, Bernrard B, Daar E, Kerndt R (2007) Epidemiologic investigation of a cluster of workplace HIV infections in the adult film industry: Los Angeles, California 2004. Clin Infect Dis 44:301-305

21. Leitner T, Escanilla D, Franzen C, Uhlen M, Albert J (1996) Accurate reconstruction of a known HIV transmission history by phylogenetic tree analysis. Proc Natl Acad Sci USA 93:1086410869

22. Kaye M, Chibo D, Birch C (2009) Comparison of Bayesian and maximum-likelihood phylogenetic approaches in two legal cases involving accusations of transmission of HIV. AIDS Res Human Retroviruses 25:741-748

23. Leitner T, Foley B, Hahn B, Marx P, McCutchan F, Mellors J, Wolinsky S, Korber B (2007) HIV Sequence Compendium 2006/ 2007. Los Alamos National Laboratory, Los Alamos

24. Van der Bij AK, Dukers NH, Couthino RA, Fennema HS (2008) Low HIV testing rates and awareness of HIV infection among high-risk heterosexual STI clinic attendees in The Netherlands. Eur J Public Health 18:376-379

25. Boerma JT, Stansfield SK (2007) Health statistics 1. Health statistics now: are we making the right investments. Lancet 369:779-786

26. Coates TJ, Richter L, Caceres C (2008) Behavioural strategies to reduce HIV transmission: how to make them work better. Lancet 372:669-684

27. Knapper CM, Roderick J, Smith J, Temple M, Birley HD (2008) Investigation of an HIV transmission cluster centred in South Wales. Sex Transm Infect 84:377-380

28. Mitchell CM, Kaufman CE, Beals J (2004) Identifying diverse HIV risk groups among American Indian young adults: the utility of cluster analysis. AIDS Behav 8:263-275

29. Ndumbe P, Atchou G, Biwole M, Lobe V, Ayuk-Takem J (1993) Infections among pygmies in the Eastern province of Cameroon. Med Microbiol Immunol 182:281-284

30. Wicker S, Rabenau HF, Gottschalk R, Doerr HW, Allwinn R (2007) Seroprevalence of vaccine preventable and blood transmissible viral infections (measles, mumps, rubella, polio, HBV, $\mathrm{HCV}$ and HIV) in medical students. Med Microbiol Immunol 196:145-150

31. Stürmer M, Doerr HW, Gürtler L (2009) Human immunodeficiency virus: 25 years of diagnostic and therapeutic strategies and their impact on hepatitis B and C virus. Med Microbiol Immunol 198:147-155 